\author{
Hana Voisine-Jechova \\ emerytowany profesor Université Paris IV \\ e-mail: hanavois123@hotmail.com
}

\title{
Przestrzeń senna jako aspekt narracji u Brunona Schulza i jego poprzedników
}

Tytuł mojego artykułu odsyła do pewnego typu opisu antymimetycznego czy raczej wielowarstwowego, charakterystycznego dla Schulza oraz pewnych pisarzy i malarzy jego epoki, typu występującego w różnych formach także $\mathrm{u}$ twórców epok poprzednich, niedającego się jednak identyfikować wyłącznie z poetyką snu. Wskazać można by tutaj cały szereg różnych wizji i komentarzy do rzeczywistości, w których marzenia przeplatają się z pierwiastkami fantastycznymi lub z konceptami wynikającymi z imaginacji poetyckiej ${ }^{1}$. Czasami trudno jest określić, które z nich i pod jakim względem należą do tej lub innej kategorii. $Z$ tego wynika trudna do zdefiniowania, dynamiczna wielorakość, w której rzeczywistość staje się pytaniem, wątpieniem i drogą do sfer nieuchwytnych. Nerval powiedział, że sen to drugie życie², Schulz napisał zaś Republikę marzeń. U pisarzy i malarzy szukających sensu istnienia poza obszarem rzeczy tego, co codzienne i "sprawdzalne”, aluzje do snów i marzeń występują obficie. Paul Valéry, jak i wielu innych, pokazał, że każdy z nas żyje po wielokroć, a z tego wynika, że doświadczamy też więcej marzeń i snów, w których znajduje odbicie szereg doświadczeń

1 W Stowniku Schulzowskim czytamy: „W niektórych użyciach fantastyka bywa u Schulza synonimem »marzenia« i »wyobraźni«" (Słownik Schulzowski, oprac. i red. W. Bolecki, J. Jarzębski, S. Rosiek, Gdańsk, s. 114).

2 „Marzenie - to życie wtóre. Bez drżenia nie przekraczałem nigdy tych drzwi z kości słoniowej czy rogu, które oddzielają nas od świata niewidzialnego" (G. de Nerval, Aurelia, w: tegoż, Sylwia i inne opowiadania, przeł. L. Choromański, Warszawa 1960, s. 7). 
związanych z przeżyciami intymnymi, z życiem zewnętrznym, z wyobraźnią zbiorową i indywidualną... W twórczości artystycznej tego typu istotną rolę odgrywa ponadto aspekt estetyczny, nakaz wynikający ze środków wyrazu, ich konotacji i tradycji.

Tylko z takiego „wielorakiego" punktu widzenia można zajmować się przestrzenią u Brunona Schulza i jego poprzedników. Przenikają się w niej pierwiastki antymimetyczne, $\mathrm{w}$ różnych ujęciach onirycznych, $\mathrm{z}$ pierwiastkami pozornie mimetycznymi, które również przejawiają się rozmaicie. Na pierwszy rzut oka takie opisy przestrzeni wykluczają zwykłe następstwo zdarzeń, w pewnym sensie jednak nawiązują do szerokiej tradycji literackich opisów krain rzeczywistych i nierzeczywistych, utopijnych, wymarzonych oraz zmyślonych.

Różne warstwy rzeczywistości istniały w opisach literackich od zawsze, wydaje się jednak, że w zasadzie respektowano granicę między światem naocznym, sprawdzalnym i światem fantastycznym, zrodzonym z wierzeń lub marzeń pisarza i jego epoki. W poematach średniowiecznych wiadomo, gdzie znajduje się ziemia, a gdzie niebo, $w$ różnych zaś przedstawieniach renesansowych i barokowych sfera ziemska oddzielona jest materialnie od sfery niebieskiej i piekielnej. Od początku XIX wieku jednak granica między różnymi warstwami egzystencji niekiedy zaciera się, a czasami nawet znika. Bohater Aurelii z opowieści Nervala rozmawia z przyjaciółmi w Paryżu, w miejscach dość banalnych, o malarstwie i muzyce. Jeden z nich odprowadza go do domu. Najpierw idą normalnymi ulicami, jednak w pewnym momencie przyjaciel upodabnia się do apostoła, a bohater znajduje się w miejscu, które traci kształt miasta... Czy jest to zmiana krajobrazu, czy raczej przemiana uczuć i myśli bohatera, jego nowe nieuchwytne istnienie? Przestrzeń nakłada się na jego świadomość, staje się nią. Wprawdzie zarówno w powieściach realistycznych, jak i utopijnych człowiek także ukazywany bywał $\mathrm{w}$ rozmaitych miejscach, był z nimi konfrontowany, a one wywierały wpływ na jego losy, ale równocześnie pozostawał od nich oddzielony, zachowywał swoją tożsamość. Natomiast u Nervala staje się w pewnym stopniu tym, co widzi, identyfikuje się z tym, co go otacza.

Czeski poeta romantyczny Karel Hynek Mácha opisuje pozornie banalną wycieczkę w góry, podczas której krajobraz zmienia się w wizję nieistniejącego wcześniej klasztoru. Wychodzą z niego przywróceni do życia na jeden dzień mnisi, bohater zaś ginie, nie wiadomo, czy popełniając samobójstwo, czy też ulegając siłom nadprzyrodzonym. To nie on sam się zmienił, a przynajmniej poeta nic nie pisze o tym, co się działo $z$ bohaterem podczas wycieczki. Do fatalnego rozwiązania akcji doprowadziła zmiana przestrzeni czy też jej wizji. Czy była to jednak tylko zmiana przestrzeni? 
Ani $\mathrm{u}$ francuskiego, ani $\mathrm{u}$ czeskiego poety przejście $\mathrm{z}$ jednego miejsca do drugiego, czy raczej metamorfoza, nie wynikają z interwencji sił nadprzyrodzonych. Bohaterowie utworów nie znajdują się w sposób jednoznaczny „po drugiej stronie lustra” i nie możemy być pewni, że to, czego doświadczają dzieje się jedynie we śnie. Między opisem mimetycznym miejsca i jego antymimetycznym przekształceniem nie ma logicznego przejścia. Przestrzeń wymyka się ludzkiemu pojmowaniu, jest nieuchwytna i fatalna, a jednak decyduje o formach istnienia i śmierci. Staje się ona wyznacznikiem wątku fabularnego prowadzącym do rozwinięcia i zakończenia akcji ${ }^{3}$.

Do spuścizny owego subiektywnie romantycznego, fantastycznie psychologicznego ujęcia przestrzeni pisarze i malarze końca XIX i początku XX wieku nawiązywali w sposób rozmaity.

\section{Wielowarstwowy opis i narracja w prozie Brunona Schulza}

Ujęcie przestrzeni u Schulza przypomina charakterystyczne dla romantyzmu zacieranie granic pomiędzy imaginacją poetycką, urojeniami i wizjami sennymi, równocześnie jednak znajduje się w całym kompleksie wizji „indywidualnych", w których czasami trudno odróżnić opis metaforyczny doświadczalnego świata od konstrukcji nowej rzeczywistości, podlegającej odmiennym prawom. Przestrzeń pełni u niego, podobnie jak u wszystkich prawie autorów fikcji narracyjnej, funkcję tła, na którym rozgrywa się akcja, i równocześnie jest miejscem samodzielnym, przekształconym przez percepcję narratora albo postaci, związanym z akcją na zasadzie różnych konfrontacji, a czasami zastępującym ją lub modyfikującym jej wydźwięk. Wydaje się jednak, że owa druga funkcja opisu przestrzeni nabiera u Schulza specjalnego znaczenia, zbliżając jego utwory do malarstwa epoki.

Opowiadania ze Sklepów cynamonowych i Sanatorium pod Klepsydrą są pozornie chaotycznym splotem wydarzeń związanych z rodziną narratora. Te same wątki powtarzają się tu i przekształcają w ujęciach poetycko-mimetycznych i karykaturalno-fantastycznych, a granica między ich różnymi znaczeniami zaciera się. Nie chodzi tylko o zderzenie oraz przeplatanie prze-

\footnotetext{
3 Przestrzeń przekształca się w percepcji ludzi pod wpływem narkotyków albo w związku z różnymi chorobami oraz nienormalnymi stanami nerwowymi. Wizje Nervala można interpretować $\mathrm{w}$ ten sposób, jednak moim zdaniem chodzi u niego przede wszystkim o pewne ujęcie estetyczne i filozoficzne, w którym zaciera się granica między mimetycznym i antymimetycznym stosunkiem do rzeczywistości.
} 
strzeni wewnętrznego doświadczenia (albo raczej wewnętrznych doświadczeń) ${ }^{4} \mathrm{z}$ różnymi przestrzeniami reprezentującymi świat zewnętrzny.

U Schulza istnienie ma cechy biblijne, porównywane jest do Księgi ${ }^{5}$, „rzeczy bez nazwy, której sam pierwszy posmak na końcu języka przekracza pojemność naszego zachwytu" ${ }^{6}$. Przestrzeń staje się czasami częścią „księgi” - rzeczywistość "zewnętrzna” wprowadza do świata duchowego. Na przykład w opowiadaniu Księga wiatr „kartkował [...] arkusze [księgi]”, a ta „ulatywała, rozsypując się, stronica za stronicą i wsiąkała łagodnie w krajobraz, który syciła barwnością" [s. 162], w Drugiej jesieni czytamy zaś:

Jesień, jesień, aleksandryjska epoka roku, gromadząca w swych ogromnych bibliotekach jałową mądrość 365 dni obiegu słonecznego. O, te poranki starcze, żółte jak pergamin, słodkie od mądrości jak późne wieczory! Te przedpołudnia uśmiechnięte chytrze jak mądre palimpsesty, wielowarstwowe jak stare pożółkłe księgi! [...] Każdy krajobraz jest mu jak wstęp do starego romansu [...] [s. 291].

Obszary „sakralne” zderzają się jednak u Schulza ze światem bluźnierstwa i karykatury. Dotyczy to również wizji krajobrazu. Połączenie krajobrazu z kartkami „księgi” lub z rysunkami na mapie przynależy do sfery zjawisk sztucznych, wynikających z nastawienia estetycznego, a niekiedy nawet mistycznego, ale też zdegradowanych do poziomu tandety, zbliżonych do teatru prowincjonalnego czy miernych obrazów w muzeum miejskim. Widok okolicy miasta odwija się ze starej i pięknej mapy, którą „ojciec przechowywał w dolnej szufladzie swego głębokiego biurka" [Ulica Krokodyli, s. 121]. To, co jest oddalone $\mathrm{w}$ przestrzeni - a tym samym i w czasie, bo te dwa aspekty są, i to nie tylko u Schulza, ściśle związane - ma poetycki urok tradycyjnego piękna. Nowa dzielnica miasta przedstawiona została odmiennie, w sposób degradujący:

Tylko linie kilku ulic wrysowane tam były czarnymi kreskami i opatrzone nazwami $\mathrm{w}$ prostym nieozdobnym piśmie, $\mathrm{w}$ odróżnieniu od szlachetnej antykwy innych napisów. Widocznie kartograf wzbraniał się uznać przynależność tej dzielnicy do zespołu miasta i zastrzeżenie swe wyraził w tym odrębnym i postponującym wykonaniu. Aby zrozumieć tę rezerwę, musimy już teraz zwrócić uwagę na dwuznaczny i wątpliwy charakter tej dzielnicy [...] [Ulica Krokodyli, s. 122].

${ }^{4}$ Chodzi o przestrzeń, której nie można sprawdzić geometrycznie, a którą Ludwig Binswanger określa terminem „der gestimmte Raum” (Das Raumproblem in der Psychopathologie, Berlin 1933).

5 Na ten temat zob.: J. Błoński, Świat jako Księga i komentarz. O żydowskich źródłach twórczości Brunona Schulza, „Polonistyka” 1993, nr 4, s. 198-204.

6 B. Schulz, Proza, Kraków 1964, s. 161. Dalej numer strony podaję bezpośrednio po cytacie. 
Niejasność, dwoistość przestrzeni właściwa jest całej twórczości Schulza. Rzeczywistość pozorna staje się rzeczywistością nierealną w opowiadaniu $S a$ natorium pod Klepsydra, w którym przestrzeń sklepu rozszerza się „w panoramę jesiennego krajobrazu, pełną jezior i dali", staje się Synajem wyrosłym z gniewu ojca, itd. Opisy owe przekraczają poziom zwykłych porównań, bo granica między comparatum i comparandum jest osłabiona albo znika.

Istnieją pewne związki między wyobraźnią barokową a postawą estetyczną ekspresjonistów. Na barokowych obrazach sceny biblijne często obramowane są kurtyną i to stwarza iluzję inscenizacji teatralnej, prowadzącej do podważenia ich realności. W epoce, która podkreśla subiektywność (i chwiejność) percepcji świata, owa perspektywa nabiera wprawdzie nowych znaczeń filozoficznych i estetycznych, zasadnicze napięcie między światem „rzeczywistym" (do którego nie mamy bezpośredniego dostępu) a światem iluzji, światem "teatralnym" jednak w niej pozostaje.

Krajobraz nabiera w tej koncepcji cech inscenizacji teatralnej: jest „ułożony kulisowo" [s. 313], „,[j]esień [...] jest wielkim wędrownym teatrem kłamiącym poezją" [Druga jesień, s. 290], a dziwaczny instrument, który bohater otrzymuje zamiast zamówionej książki, przypomina coś „na kształt długiego auta $\mathrm{z}$ lakowego płótna, jakiś rekwizyt teatralny imitujący w lekkim materiale papieru i sztywnego drelichu masywność rzeczywistości" [s. 324-325].

Metafory, różne rodzaje porównań i opisy realistyczne przeplatają się. Obok „teatralnej” wizji otaczającego świata znajdujemy u Schulza też aluzję do „prawdziwego" spektaklu. Jest jednak znamienne, że iluzja teatralna nie dochodzi do skutku. Zamiast zanurzyć się w złudzeniu fikcji zdefiniowanej, bohater po nieudanej wizycie $w$ teatrze doświadcza niejednoznacznych metamorfoz:

Maski trzepotały czerwonymi powiekami, kolorowe wargi szeptały coś bezgłośnie i wiedziałem, że przyjdzie chwila, kiedy napięcie tajemnicy dojdzie do zenitu i wtedy wezbrane niebo kurtyny pęknie naprawdę, uniesie się i ukaże rzeczy niesłychane i olśniewające.

Lecz nie było mi dane doczekać tej chwili [...] [Sklepy cynamonowe, s. 110].

Inspiracje barokowe w twórczości Schulza są niewątpliwe, mają jednak charakter skomplikowany. Schulz był nie tylko pisarzem, ale też malarzem, grafikiem, rysownikiem.. Porównując jego rysunki z opisami literackimi, wkraczamy w sferę swoistych dla niego kontrastów i analogii. Krajobrazy $\mathrm{w}$ jego opowiadaniach są kolorowe i to prowadzi czasami do pewnego, typowego dla malarstwa barokowego, zachwiania konturów. Jeżeli przestrzeń pozostaje bezbarwna, to jest to wyraz degradacji. Rysunki natomiast są "szare", napięcie emocjonalne wynika $\mathrm{w}$ nich $\mathrm{z}$ innych założeń (i osiągane jest przy 
pomocy innych środków), z prowokacyjnej sztywności, na pierwszy rzut oka przeciwnej inspiracji barokowej. Czy jest to kontrast pozorny, czy też tylko inny wyraz nieuchwytnej dwoistości towarzyszącej całej twórczości Schulza? Pod względem tematycznym obie dziedziny łączą się.

Opis przestrzeni wiąże się ze strukturą tematyczną i jej ujęcie zmienia się wraz ze zmianą tematu. Przedstawiając dalekie horyzonty, autor posługuje się innymi środkami niż wtedy, gdy ukazuje dzielnice miejskie. Obrazy ogrodów zanurzonych w chwastach przedstawiane są inaczej niż obrazy pustych pokojów. Owe różnice nie są jednak konsekwentne, czasami jedne obrazy odbijają się $\mathrm{w}$ drugich - sklep falujący suknami podobny jest do miejsca falującego wegetującą roślinnością.

Co najmniej jednak dwa wyobrażenia przestrzeni mają u Schulza charakter konstanty, będącej nośnikiem filozoficznej wymowy opowiadań. Jest to labirynt i zamurowane drzwi, za którymi znajdują się zapomniane pomieszczenia. W opowiadaniu Sklepy cynamonowe bohater, zgubiwszy się w drodze do domu, błąka się w labiryncie miejsc nieprawdopodobnych. W Traktacie o manekinach motyw zamurowanych drzwi oznacza bezruch, nieistnienie:

w starych mieszkaniach bywają pokoje, o których się zapomina. Nie odwiedzane miesiącami, więdną w opuszczeniu między starymi murami i zdarza się, że zasklepiają się $w$ sobie, zarastają cegłą i, raz na zawsze stracone dla naszej pamięci, powoli tracą też swą egzystencję. Drzwi, prowadzące do nich z jakiegoś podestu tylnych schodów, mogą być tak długo przeoczane przez domowników, aż wrastają, wchodzą $\mathrm{w}$ ścianę, która zaciera ich ślad $\mathrm{w}$ fantastycznym rysunku pęknięć i rys [s. 90-91].

Czasami jednak labirynt i przestrzeń zdegradowana, prawie nieistniejąca, są identyczne, jak na przykład w niekończącej się podróży bohatera wyjeżdżającego z "sanatorium pod Klepsydrą" czy w opowiadaniu Nawiedzenie.

Mieszkaliśmy $\mathrm{w}$ rynku, $\mathrm{w}$ jednym $\mathrm{z}$ tych ciemnych domów o pustych i ślepych fasadach, które tak trudno od siebie odróżnić.

Daje to powód do ciągłych omyłek. Gdyż wszedłszy raz w niewłaściwą sień i na niewłaściwe schody, dostawało się zazwyczaj w prawdziwy labirynt obcych mieszkań, ganków, niespodzianych wyjść na obce podwórza i zapominało się o początkowym celu wyprawy, ażeby po wielu dniach, wracając z manowców dziwnych i splątanych przygód, o jakimś szarym świcie przypomnieć sobie wśród wyrzutów sumienia dom rodzinny [s. 57].

We wszystkich tych przypadkach opis przestrzeni wkracza tematycznie do struktury akcji, staje się częścią narracji. 


\section{Przestrzeń falująca i ruchliwa}

Jak już wspomniano, przestrzeń ujęta jest u Schulza „barokowo"7. To przestrzeń fałdzista, pełna zakrętów, niepewna i nieuchwytna, zawsze zmieniająca się, ruchliwa. Istnieje ona w sposób odmienny niż człowiek, ma własną egzystencję, czasami nawet intensywniejszą niż ludzka. O ile bohater "ludzki" bywa niekiedy sztywny, upodabniając się do manekina, którego cienie towarzyszą także postaciom na rysunkach Schulza, o tyle przestrzeń, zaktualizowana w poetyckiej wizji, pozostaje dynamiczna, złożona ze wszystkich żywiołów: ziemi, powietrza, ognia i wody. Istnienie ziemskie zostaje wyraźnie utożsamione z żywiołem wody.

Cały ten ciemny krajobraz [...] zdawał się ledwie dostrzegalnie płynąć sam w sobie $[\ldots]$.

Albo:

Cały krajobraz jest jakby dnem ogromnego akwarium $-\mathrm{z}$ bladego atramentu. Drzewa, ludzie i domy zlewają się w czarne sylwetki falujące jak rośliny podwodne na tle tej atramentowej toni [Sanatorium pod Klepsydra, s. 334].

Przestrzeń (ziemia) znajduje się jednak też w sferze powietrza, przez które jest ciągle przekształcana. Między „pływaniem” i „lataniem” nie ma zasadniczej różnicy.

Okno pokoju, pełne po brzegi nieba, wzbierało tymi wzlotami bez końca i przelewało się firankami, które całe w płomieniach, dymiąc w ogniu, spływały złotymi cieniami i drganiem słoi powietrznych. Na dywanie leżał ukośny, pałający czworobok, falując blaskiem, i nie mógł oderwać się od podłogi [Genialna epoka, s. 179].

Okno pokoju ograniczone jest „brzegami” i „przelewa się", na dywanie "faluje blaskiem" czworobok, równocześnie jednak owo okno jest otoczone "drganiem słoi powietrznych". Oświetlona część wydaje się być istotą żyjącą, leży na dywanie, nie może oderwać się od podłogi. Połączeniu pływania i wzlatywania towarzyszy obecność ognia, dymu i złotych płomieni. W pewnym sensie chodzi w tym syntetycznym przedstawieniu o ekspresjonistyczną adaptację poetyckich „korespondencji”.

7 W tym wypadku można odwołać się do teorii G. Deleuze'a wyłożonej w pracy: G. Deleuze, Le Pli. Leibniz et la baroque, Paris 1988. 
Obecność powietrza w opisach przestrzeni znajduje odbicie w sposobie rozwijania akcji. Bohaterowie Schulza często się wznoszą. Emeryt, porwany przez wiatr, leci „wysoko nad dachami” i znika [Emeryt, s. 380], ciotka Perazja w czasie wichury kurczy się, obiega ściany kuchni, by wreszcie „skruszyć [się] w proch i w nicość" [Wichura, s. 144]. Istnieje pewna analogia między „latającymi" postaciami z opowiadań Brunona Schulza i jego rysunkami, na których postacie też czasami „wznoszą się" ${ }^{8}$. Podobna perspektywa występuje u Stanisława Ignacego Witkiewicza ${ }^{9}$ i innych. Najwyraźniej jednak przenika ona do obrazów Chagalla, artysty pochodzącego z tego samego środowiska, co Schulz ${ }^{10}$. Przestrzeń przekształca się $w$ wizję dwutorowego świata. Akcja rozgrywa się $\mathrm{w}$ otoczeniu banalnym, uchwyconym $\mathrm{z}$ detalami (u Chagalla są to na przykład „realistycznie” pokazane domy i domki), bohaterowie jednak wznoszą się, wstępują w świat rzeczywistości sennej czy raczej w świat rzeczywistości przeżyć wewnętrznych ${ }^{11}$. Jeżeli jednak obrazy Chagalla zawierają w sobie wizję natchnień i pewnej aprobaty świata, to u Schulza pojawia się zwątpienie i nicość. Ciotka zmienia się w proch, „przestrzeń traci swój sens” [s. 254]. Bohater Sanatorium pod Klepsydra ma wrażenie, że:

Pokój zapełnia się chrapaniem jak kłębami chmur, które rosną, piętrzą się, podnoszą na swym skłębieniu Doktora Gotarda wraz z jego łóżkiem, coraz wyżej i wyżej - wielkie patetyczne wniebowstąpienie na falach chrapania i wzdętej pościeli [s. 333].

I to prowadzi go do zwątpienia wyrażonego pytaniem: „Gdzież jestem? Co się tu dzieje? W jaką matnię wplątałem się?" [s. 333].

\section{Przenikanie się miejsca i czasu}

Z filozoficznego i estetycznego punktu widzenia czas i przestrzeń zawsze są połączone, chociaż ich koegzystencja przejawia się w sposób skomplikowany. U Schulza owo połączenie wynika już z podstawowego zamierze-

\footnotetext{
8 Na przykład „Ojciec lecący nad stołem” albo „Szymcio porwany przez wiatr”. Zob. Słownik Schulzowski, s. 135 i 415.

9 Na przykład „Kuszenie świętego Antoniego”. Zob. Słownik Schulzowski, s. 135.

$10 \mathrm{Na}$ analogię Schulza i Chagalla zwróciła uwagę Lucyna Kozikowska-Kowalik w artykule Ukształtowanie przestrzeni w utworach Brunona Schulza, „Rocznik Komisji Historycznoliterackiej” 1979 , t. 16 , s. 160.

11 W przypadku malarstwa Chagalla ujęcie to uważane jest za pewien typ realizmu psychologicznego.
} 
nia opowiadań, w których przestrzeń jest „ruchliwa”, zmieniająca się, a więc podlegająca czasowi: "Świat leżał głuchy, rozwijał się i rósł gdzieś w górze, gdzieś z tyłu i w głębi - błogo bezsilny - i płynął" [Wiosna, s. 208].

Poza tym jednak współistnienie miejsca i czasu występuje również na poziomie tematycznym. Przestrzeń jest związana z porami roku, a także z porami dnia. Różnica między miejscem i czasem zanika.

Wertowaliśmy, odurzeni światłem, w tej wielkiej księdze wakacji, której wszystkie karty pałały od blasku i miały na dnie słodki do omdlenia miąższ złotych gruszek [Sierpień, s. 47].

Trudno zdefiniować wszystkie aspekty owej syntetycznej i dynamicznej wizji. Jest to letnia pora wakacji, więc pewien fragment czasu. Jednocześnie jednak jest to „wielka księga”, wymykająca się jednoznacznej interpretacji. Karty owej księgi „miały na dnie [...] słodki do omdlenia miąższ złotych gruszek". Zwrot "dno kart” jest nacechowany przestrzennie, ale czy mamy tu naprawdę do czynienia z przestrzenią, czy też blask i słodycz oznaczają tylko percepcje zmysłowe? Przenikanie się czasu i miejsca prowadzi do intensywnych wrażeń, które trudno rozłożyć na poszczególne pierwiastki.

O ile przestrzeń „ziemska” staje się „ruchliwa” w imaginacji narratora, o tyle przestrzeń sklepienia niebieskiego, na tle której rozgrywa się akcja, zmienia się niejako ze swojej natury, zwłaszcza między wieczorem i rankiem.

Konstelacje stały już stromo na głowie, wszystkie gwiazdy przekręciły się na drugą stronę, ale księżyc, zagrzebany w pierzyny obłoczków, które rozświetlał swą niewidzialną obecnością, zdawał się mieć przed sobą jeszcze nieskończoną drogę i, zatopiony w swych zawiłych procederach niebieskich, nie myślał o świcie [Sklepy cynamonowe, s. 118].

Nie trzeba dodawać, że nawet $\mathrm{w}$ tym przypadku obraz jest wielowarstwowy, gdyż personifikowany firmament ma kształt "nieruchomy” (konstelacje stały, gwiazdy przekręciły się) i równocześnie „porusza się” („księżyc [...] zdawał się mieć przed sobą jeszcze nieskończoną drogę i [...] nie myślał o świcie"). Połączenie nieruchomości i ruchu jest jedną z typowych cech zarówno utworów literackich Schulza, jak i jego grafik. W tym właśnie kontekście identyfikacja czasu i przestrzeni nabiera specyficznego znaczenia.

\section{Przeżycia w przestrzeni „niekonsekwentnej”}

Jak już wspomniano, sen, fantastyka, imaginacja i rzeczywistość realna przenikają się $\mathrm{w}$ opisach przestrzeni, która $\mathrm{w}$ tym przypadku przestaje pełnić tylko (albo przede wszystkim) funkcję obramowania akcji, stając się pewnym 
rodzajem samodzielnej narracji. Przejście z jednej dziedziny do drugiej (od opisów mimetycznych do antymimetycznych) nie zostaje wyjaśnione, między naocznie obserwowanym światem (albo światem, który ma sprawiać takie wrażenie) i światem imaginacji nie ma różnicy, znajdują się one na tym samym poziomie. Podobieństwo do Nervala albo Máchy uwidacznia się wtedy najwyraźniej.

Opowiadanie Sklepy cynamonowe rozpoczyna się sceną realistyczną. Narrator jest $\mathrm{w}$ teatrze, skąd wychodzi, żeby poszukać $\mathrm{w}$ domu portfela ojca. Konstelacja ulic zmienia się jednak, otwierają się „ulice podwójne, ulice sobowtóry, ulice kłamliwe i zwodne" [s. 110]. Akcja rozwija się "chaotycznie". Narrator porzuca zamiar dotarcia do domu, a miejsca, przez które wędruje, wynurzają się bez logicznego wyjaśnienia i nabierają kształtów nieprawdopodobnych. Nie wiadomo dlaczego znajduje się on tam, gdzie się znajduje, ani też dlaczego spotyka się z ludźmi, z którymi się spotyka. Ze świata doświadczeń zewnętrznych (z przestrzeni „sprawdzalnej”) przechodzi - bez autorskiego objaśnienia - do sfery imaginacji (do przestrzeni snu i fantastyki) i nie wiadomo, po której stronie znajduje się jego „prawdziwa” rzeczywistość.

W opowiadaniu tym niewyjaśnione przejście ze sfery realistycznej do fantastycznej następuje $\mathrm{w}$ narracji, która rozwija się $\mathrm{w}$ czasie. Bohater jest najpierw w "normalnym” teatrze, a potem - nie wiadomo w jaki sposób gdzieś indziej. W większości utworów Brunona Schulza owe dwa światy, realistyczny i fantastyczny, nie są jednak związane z mijaniem czasu, nie następują jeden po drugim, ale występują jako równoczesne. Wszystko, co jest, jest równocześnie jeszcze czymś innym. Czasami wynika to wprawdzie z pomyłek, z nieporozumienia, z wielotorowości „prawdziwego" świata, jak w Ulicy Krokodyli, często jednak chodzi o przeplatanie opisów "prawdopodobnych" (jak na przykład likwidowanego sklepu) z wizjami chimerycznymi (ojca ugotowanego na półmisku). Między pomyłką, nieporozumieniem i fantastycznym przekształceniem świata nie ma wyraźnych granic.

\section{Zakończenie}

W opisach przestrzeni u Schulza znajdują odbicie dwie postawy: 1) mistyczne zachwycenie sacrum $\mathrm{w}$ świecie, $\mathrm{w}$ którym rzeczy, przechodzące $\mathrm{z}$ istnienia "zewnętrznego" do „sensu” wynikającego z imaginacji i z wizji sennych, utożsamiają się z Księgą stworzenia i 2) poczucie degradacji, która z tandety towarów, domów, ulic czy wozów pełnych śmieci i słomy przenika do egzystencji ludzkiej, jest egzystencją ludzką. Rzeczywistość przestaje być rzeczywistością, jest tylko imitacją, pozorem, konstrukcją z papieru. Trudno 
uchwycić jej prawdziwy charakter i to nie tyko w Ulicy Krokodyli, w której narrator przyznaje:

Język nasz nie posiada określeń, które by dozowały niejako stopień realności, definiowały jej gęstość. Powiedzmy bez ogródek: fatalnością tej dzielnicy jest, że nic $\mathrm{w}$ niej nie dochodzi do skutku, nic nie dobiega do swego definitivum, wszystkie ruchy rozpoczęte zawisają w powietrzu, wszystkie gesty wyczerpują się przedwcześnie i nie mogą przekroczyć pewnego martwego punktu [s. 131].

Jest to wizja klęski, obraz ruchu, który przestaje być ruchem, rzeczywistości, która przestaje być rzeczywistością. Równocześnie jednak odbija się w niej tendencje epoki, która zachwycała się (zachwycała się naprawdę?) tym, co "sztuczne" 12 .

Opisom „ruchliwej” przestrzeni towarzyszą, a czasami się z nimi przenikają, opisy ucieczek, niekończących się podróży, które nie prowadzą do żadnego celu. Można zgodzić się z autorami Słowniku Schulzowskiego, że „,[w] symbolice podróży zawarte jest oczekiwanie upadłego świata ulicy Krokodyli na wybawcę, który uporządkuje rzeczywistość" ${ }^{13}$. Można jednak też powiedzieć, że opis przestrzeni i wydarzeń z nią związanych nie ogranicza się u Schulza do komentarzy na temat zewnętrznego świata, ale zwraca się ku imaginacji, wyraża emocjonalne napięcie i prowadzi do pytań o sens ludzkiego istnienia.

\section{Oneiric Space as an Aspect of Narration of Bruno Schulz and His Predecessors}

\section{Summary}

The object of analysis in this article is a type of multi-layer description characteristic of Schulz and certain writers and painters of his era. According to the author, Schulz's descriptions of space include a reflection of two attitudes: 1) a mystical rapture by the sacral world and 2) a sense of degradation of human existence. Simultaneously, however, what manifests itself in them is a fascination with the artificiality typical of the era in which he worked.

Keywords: space, oneiric poetics, narration, literary description, Bruno Schulz

12 W Czechach w tym czasie opublikowany został manifest artyficjalizmu, którego autorami byli Toyen i Jindřich Štyrský.

13 Stownik Schulzowski, s. 403. 